law too often deters a physician from acting in his patient's best interests and from helping families face problems realistically. At present we have Catch-22. A change in the law is needed to demonstrate that a change in the law is wise and safe from abuse.

Finaily, there is a philosophical debate on the significance of life and death in which the views of such writers as Tolstoy and Camus are analysed by modern philosophers. The view that life is absurd and meaningless ('endless pointlessness') is considered to be too pessimistic. Life has meaning only in the way we set our own objectives and make our own choices. Thus, as Margolis argues, to consider death itself as intrinsically evil is arbitrary and doctrinaire - it depends on the circumstances!

In the Preface the editors indicate their confidence that this book will serve as a text for interdisciplinary discussions on the issues of death and dying in our technologically advanced society. Overall, I think that this confidence is justified. In whole or in parts it should be helpful to students and practitioners of medicine and law. (It is of course primarily concerned with American law). There are one or two editorial slips such as incomplete references, but overall the book is well written, well produced and available in paperback at reasonable cost. Many of the contributors are familiar to this reviewer, but some are not. Unfortunately, we are not told who they are - not even their professional or academic affiliations. Brief biographical notes would have helped.

A G M CAMPBELL

\section{Contemporary Issues in Biomedical Ethics}

John W Davis, Barry Hoffmaster and Sarah Shorten (Eds).

Humana Press, I978, 300 pp. \$I9.50.

This book is a collection of papers and comments thereon originally delivered at a Colloquium on Biomedical Ethics at the University of Western Ontario in 1977, with a foreword by Daniel Callahan of the Hastings Center.

Because the term 'biomedical' is susceptible of a wide definition the essays are a selection which have this in common, that they are observations on recent advances in biology and the health sciences which have created a need to re-assess the practice of medicine and the attitudes and values of society. There are five parts: rights and moral decisions, issues in genetics, the role of the physician, informed consent and paternalism, and professional responsibility.

In the first four parts, each main contribution is followed immediately by comment and criticism, but for some reason, which is not immediately apparent, this useful and stimulating technique has not been adopted in the fifth part where the essays are no less provocative, but the authors' views nevertheless appears unchallenged.

The book opens with an essay by John Ladd entitled 'Legalism and Medical Ethics', where legalism is defined as 'the ethical attitude that holds moral conduct to be a matter of rule following, and moral relationships to consist of duties and rights determined by rules'. In his view, legalism is an inappropriate device for discussing medical ethics. Because of its association with rights, it entails 'the legalisation of morality and the moralisation of law'. Ladd would prefer a more individualistic approach based on moral relationships and duties. His stance fails to meet with the approval of Hoffmaster whose principal objection is that Ladd's approach does not amount to a theory of ethical conduct, in other words it fails to identify the characteristics of right action and to provide a method for choosing between alternatives.

Robert Audi's essay on 'The Moral Rights of the Terminally IIl' supports the notion of rights and he is of the view that conflicts of rights create the main problems in medical ethics. He attempts to clarify the idea of 'rights' and how to deal with conflicts and he begins by arguing that there is a moral distinction between killing and letting a person die. He goes on to discuss when terminally-ill patients should be allowed to refuse treatment or further treatment and thus recognises a right to control one's body, to end one's life and a right not to be lied to about one's condition. However, these rights can be overridden by more important moral considerations. Susan Sherwin does not hold with the distinction between killing and letting die nor with the view that rights in one person correlate with obligations in another.

The notion of patients' rights central to Joseph Ellin's essepy, 'Sterilisation, Privacy and the Vate of Reproduction,' which is in second section of the book. He asks whether it is rational and producte of substantial benefit to permit ofll to reproduce, rather than requirimg some not to do so, while allowngng them to adopt instead. He concluepes that it is not, but nevertheless hots that involuntary sterilisation is a violation of the right to use ores's body. He also points to ethogl statements about the 'rights' of 票e unborn which he finds unintelligi 9 In that connection, Robert Baker's essay, Protecting the Unconceived and Michael Bayles' observations thereon are instructive. Both agdee on the vagueness of the term 'genetic', a point which is develo d in Richard Hull's contribution, th Getting "Genetic" Out of Gen Gic Disease'.

In the third section, Lisa Newean suggest that modern medicine has rendered the Hippocratic princiges otiose in that the practice of medisise is no longer for the select few, fut Donald Zafras feels that moxh remains of Hippocratic doctione which is worth preserving and can be adapted to modern trerois. Bayles puts forward the view that the physician is a 'body mechar 㮃', in other words, the doctor patent relationship is fiduciary rather contractual and he argues that physician must be licensed oto 'practise' and must obtain permission before performing mifor 'repairs'. Colleen Clements rejegts this notion inter alia because Bayfes premise depersonalises the role $J_{\text {of }}$ the doctor.

In one of the essays in the foumth part, Bernard Dickens details the legal requirements for inforried consent, its elements, the requifid standards and he mentions somenof the problems which can arise with the mentally ill and those under ase. This is complemented by Gien Graber and Ellin's discussion $\bar{D}_{\mathrm{of}}$ 'Paternalism and Health Care' and also Dan Brook and Bruce Miller $8 n$ the 'Involuntary Commitment Ofof the Mentally Ill'.

The last part of the book conta就 three essays, one by Arthur D $\frac{0}{8} k$ who emphasises the importance of compassion and suggests that students can be taught how to compassionate. Josephine Flahs 
considers the role of nurses and thinks that because they are an essential part of health care, they are accountable for their activities and not merely answerable to some higher authority. That means that they must adopt a critical attitude to others involved in health care and should address their minds to issues rather than accept the views of others. The final contribution, by David Roy, states that philosophers have a responsibility to the public to develop a system of values which will serve as a guide in dealing with these biomedical issues. He feels that universal ethical standards should be developed by reference to the nature of things rather than man whose nature is subject to radical change.

These essays are of a high standard and they point emphatically to the need for an interdisciplinary approach to the issues with which they seek to grapple. They should appeal to the lay and the profession alike, but the lay person may at times wonder where he has got to, when he finds one view convincingly presented, only to find it attacked in the immediately following pages. Perhaps he should not be discouraged by this, in that none of the essayists claims that the issues have simple solutions. It is hoped that these essays and others like them will be used by students of medicine, law and philosophy to their certain advantage.

\section{J CUSINE}

\section{Illness as Metaphor}

\section{Susan Sontag}

Allen Lane, I979, 88 pp. £3.95.

In this book Susan Sontag sets out to discuss the way in which men have through much of human history employed their fantasies about illness as metaphors. She is particularly concerned with tuberculosis (in the I9th century) and cancer (now). It is these two diseases which in the popular mind have been seen as mysterious, as 'intractable and capricious', as a 'ruthless, secret invasion', the diagnosis of which was felt to be a sentence of death. Both diseases were originally named from the external swellings or lumps which were their earliest manifestations in some sufferers, and in both the body seems to waste away. But although at first the images of the two were equivalent, the fantasies developed differently, those of TB being of a romantic or spiritualised nature, focussing on the lungs, while in those of cancer it is the invasive diffusion of the disease to less respectable organs (mainly 'below the belt') which is emphasised. TB is imagined as marked by an excess of passion, while (the author suggests) cancer is now held to be 'the wages of repression'.

Having shown how such fantasies, enshrined in literature, have grown progressively further away from the reality of the disease, the author goes on to discuss the punitive notions often attached to ideas of illness and to attack those which link the patient's disease to his character. From these she proceeds to discuss the language of warfare which is so often employed (by doctors as well as others) as we talk of tissue 'invasion', body 'defences' and our therapeutic 'armamentarium' which these days includes 'bombardment' of tissues to 'kill' the invader. The final chapter describes how disease metaphors are used 'to enliven charges that a society was corrupt or unjust'.

The author says that the 'healthiest way of being ill is one most purified of (and) resistant to metaphoric thinking'. But for most of the book it does not seem to be metaphor itself that she is attacking, so much as the undisciplined fantasies which cluster around the name of the illness which is used as a metaphor. (When she uses such words as metaphor, fantasy, myth or image it is often not clear whether she employs them for their common core of meaning or for their distinctiveness). Surely, it is humanly impossible to experience illness without having fantasies about it. From the sharing of such fantasies arise myths of the origin of the illness (analogous to myths of creation) which may become part of the received lore of medical as well as ordinary folk. As research and rationality are brought to bear on the matter, such fantasies and myths can be corrected and refined, but will never disappear so long as illness is experienced.

But Susan Sontag does not distinguish experiencing illness from being ill. Is someone ill if he is free of symptoms but has a tumour which he knows nothing about (until, for instance, he undergoes a clinical screening process)? By describing illness as an 'ineluctable material reality' the author would presumably answer this question affirmatively. Not everyone would agree. And she apparently thinks that being ill is strictly meaningless. 'Nothing', she says, 'is more punitive than to give disease a meaning that meaning being invariably a moralistic one'. And, arguing that in the popular imagination 'cancer equals death', she says 'As death is now an offensively meaningless event, so that disease widely considered a synonym for death is experienced as something to hide'.

Her positivist interpretation of illness leads her to attack attempts at psychological understanding of it, and she claims that 'theories that diseases are caused by mental states and can be cured by will power are always an index of how much is not understood about the physical terrain of a disease'. This is to tilt against windmills; no competent psychologist would claim that the mental state is the only cause of a somatic illness, but most would regard it as a relevant factor in the aetiology of many somatic illnesses and sometimes as offering a useful approach to treatment. (The additional clause 'and can be cured by will power' is a non-sequitur; convincing psychosomatic theories carry no such implication.) Susan Sontag has no use for theories of multiple causation, and seems to think they are discredited by the discovery of a specific treatment. Thus once streptomycin was found, aetiological factors in TB such as lack of fresh air, sunlight, adequate nutrition and exercise, and 'depressing emotions' in her view 'lose credibility'. But this is to confuse aetiology and therapy. She attacks those who (like Karl Menninger) are reluctant to 'name' cancer or to 'label' patients who have serious disease for their 'anti-intellectual pieties and a facile compassion'. She does not seem to realise that such reluctance is precisely aimed to avoid collusion with patients' exaggerated fantasies of the disease in question.

The book may perhaps be of some use as a warning against the unchecked growth of people's inevitable fantasies about illness. Otherwise, it seems to this reviewer to be ethically unhelpful, and mainly illustrative of the irritating misunderstandings which will no doubt continue to occur until (if ever) doctors and at least literate laymen can develop, and share, a 